\title{
University Of Texas Pan American, Edinburg, Texas: A Reciprocal Study Abroad Program With The Leuphana University, Lunenburg, Germany \\ Joe M. Garza, Jr., University of Texas, Pan-American
}

\begin{abstract}
This paper describes the process for expanding an existing ten year study abroad program between two universities, the University of Texas Pan American, Edinburg, Texas, and the Leuphana University, Lueneburg, Germany. The model for this reciprocal educational program will include a process for enrollment, suggested curricula, course scheduling, sources for financial aid and student living accommodations. Technology will be a resource tool to increase student access for bridging these educational barriers. This model will facilitate the process for students from both universities to study abroad for a semester while earning credits in their area of study. This paper will further address cultural diversities and language differences that may hinder communications and impede learning.
\end{abstract}

\section{INTRODUCTION}

ith the advent of the global economy and the need for business schools need to acclimate both faculty and students to this global environment. The purpose of this paper is to expand the role of study abroad between the two universities, the University of Texas Pan American at Edinburg, Texas and the Leuphana University of Lueneburg, Germany. The focus of this study will center specifically in the respective colleges of business. There is no set standard or single source of information about study abroad and the best practices relating to study abroad. Stakeholders are the university, the faculty and students keeping in mind the role for each and how it contributes to the global business society. Responsibility for implementation will fall upon each college to maintain and nurture this program to meet the needs of all stakeholders. Particular attention will be placed on students in the development of the model for implementation.

Each university identifies in its mission statement that it will prepare students education needs to meet a growing international and multicultural population through instruction. The challenge of the two colleges will center on curricular issues and the implementation of proper credit measures that must be identified to ensure equivalency. Administrative mechanisms must also be identified and be able to facilitate effective program delivery. Other issues that must be addressed include flexibility of research, creativity, and leadership roles that address the needs of the global community. Therein lies the scheduling and language education and proficiency while maximizing the cultural and international experience for it students.

\section{BACKGROUND}

This past summer, independent of each other, Leuphana University officials expressed a desire to expand its program with the University of Texas Pan American. An important factor that caused Leuphana officials to 
express their desire was that its president wanted Leuphana to emerge from a vocational certificate based college to a university degree offering program to be able to meet its objectives of becoming a global university. American university officials seek to expand their commitment to the university's mission in continuing to meeting the needs of society, especially in the rapidly changing environment of global business.

\section{OBJECTIVES}

Establish a model that will insure a smooth process for all stakeholders involved in the study abroad program within each partnering university and the two colleges of business.

Study abroad is an ongoing process and as such it is recommended that a master plan be developed and three stages of implementation be considered that incorporates the objectives with the time constraints necessary for successful and measurable outcomes that meet all institutional guidelines for such a program.

This study focuses on the development of the strategy that identifies anticipated outcomes, addresses curricular integration, the integration of foreign language, internationalization and cultural diversity, faculty involvement, recruitment of students and funding. Other important areas of consideration are to include the use of technology and the internet in research and instruction.

Based upon discussion with various university officials and review of different models of implementation, the Departmental study abroad approach offers a practical delivery method for achieving curricular integration of international topics. This departmental approach further allows students to broaden their educational perspective in their major area of study. This approach links all the vital components together to form a cohesive approach. Everyone associated with international programs must be integrated into the curriculum. This approach further provides students with a greater understanding of different cultures, customs and business practices. (Praetzel, Curcio, Dilorenzo, 1996).

Using this approach would further expose business students to internationalization to study abroad programs. Motivating students has also been a challenge for various reasons which include cost, loss of wages from part time employment and the perception of extending or interrupting the students program of regular study thus delaying their graduation and just fear of the unknown.

\section{INTERNATIONALIZATION}

In light of the increasing internationalization of the business world, the educational community is faced with responding and must recognize that "strong and growing economic forces" (AACSB 1993) are necessary. Business is under increased pressure to adjust to the internationalization of markets. "of increasing importance are the, "soft," ie., cultural and communicative factors which are today judged to account for approximately $70 \%$ of success on the international market" (Bolten, Wirtsschaftskommunikation 10). The objective of the study abroad and internationalizing the curriculum is to sensitize students to cultural differences, allowing them to function in a professional manner (Praetzel, Curcio, DiLorenzo, 1996).

It is difficult to develop an international curriculum if the faculty lacks an international perspective in their own education. There is much interest by the deans of the University of Texas Pan American and the Leuphana University to support this program. The faculty from each college represents a veritable "United Nations" of cultural diversity that increases the opportunity for advocates of such a program and strengthens the advisement of students into major courses. "Faculty who participate in overseas programs gain, first hand, the benefits of study abroad, collaborating with host institutions faculty on common research and teaching interests..."(Praetzel, Curcio, DiLorenzo, 1996 p. 177). 


\section{MODEL FOR IMPLEMENTATION}

\section{Recruitment}

A principal factor for motivating students to consider study abroad is the value derived from such a program. Curriculum and program development are among the principal methods of attracting students. The availability of a wide range of program options of varying lengths and models does not by itself result in successful recruitment.

The benefits and value of study abroad must be articulated to interest students to study abroad. The globalization of the economy and the simultaneous globalization of careers in business require professionals who can work and succeed in an international environment. Universities today are being asked to "...equip students with the necessary skills in preparation for the job market" (Sporn, 1999). In a survey taken in 1994 by Robert Kennedy, respondents from 1,250 business and industries throughout the southeast want college graduates with international business skills. (Cothran \& Gramberg, 2000, p. 148). Word of mouth, providing a "buddy system" for entering exchange students, employing returnees as program assistants on future programs, website setups as well as having advisors being actively involved in the recruitment along with faculty are different vehicles for delivering the global message (Lashbrooke, Hult, Causgil, Yaprak, Knight, 2002, p. 35 - 38).

Special efforts must be made to convince minorities from low-income families to get involved in study abroad and "to overcome the five F's: Fear, Finances, Fit, Family, and Faculty" (Lashbrooke, Hult, Causgil, Yaprak, Knight, 2002, p. 37). Families of minority and low-income students do not see the benefits or value of study abroad which results often from a lack of information. Such programs must be integrated into the fabric of the requirements of the field of study.

\section{Anticipated Outcomes}

Today study abroad programs are shifting to short-term programs from two to six weeks in length and classes are being taught in English. Its goals are varied and include the development of linguistic fluency and regional, cultural, areas of studies with emersion being the focus. There are different kinds of programs that allow for different outcomes to be achieved that include short-term travel abroad, short-term study abroad, comparative culture trips as well as long-term study abroad (Gray, 2002). To be able to properly identify educational objectives a unified classification system for study abroad programs is necessary. At a 1998 NAFSA Conference in Washington, D.C., John and Lilly proposed a five-level classification system based on seven key elements:

1. Length of sojourn

2. Foreign language proficiency prior to departure

3. $\quad$ Language used in coursework abroad

4. Context of coursework abroad (delivery mechanics...)

5. Type of housing required

6. Whether active, guided culture learning is provided

7. What sort of pre-departure and on-site orientation is provided

(Lashbrooke, Hult, Causgil, Yaprak, Knight, 2002, p.12)

Both the University of Texas Pan American and the Luephana University follow a program similar to the key elements described above. The universities seek to expand this type of program to attract a larger number of students and to go beyond taking a course but instead considering a cluster of courses that the student may draw from that could address cultural patterns and value conflicts that many managers are faced with upon international assignment (Janssens, 1995). 


\section{Curriculum Integration}

Integrating study abroad programs into established curricula is a challenge that all business schools must address. Considerations of content, rigor, quality, and accreditation requirements are also of much concern when it involves study abroad. Administration mechanisms must also be in place to ensure and facilitate effective program delivery.

Other areas of consideration are of a logistical nature. A key question is when to send students abroad. Two approaches that can be considered are by dividing university students into the lower level group consisting of freshman and sophomores and the higher level group consisting of juniors and seniors. The first group provides flexibility, the ease with which students can fit in courses into their schedule and meet general education requirements. The second group provides opportunity to implement the knowledge acquired through their course offerings (Lashbrooke, Hult, Causgil, Yaprak, \& Knight, 2002). A third group emerges from the first two which is the sophomore and junior that combines the best of having both flexibility and opportunity. In doing so, "ambassadors" for the program emerge who can serve as speakers, advisors and recruiters for the program while at the university and would provide a degree plan, and flow chart of the courses needed to fulfill university requirements for graduation.

Term coordination is another issue that is difficult to address. American and European Universities do not begin and end at the same time. European universities begin their classes in October and conclude late June or early July. The summer months present the least overlap and conflict for American students traveling abroad. This period further lends itself to the shorter course term of two to six weeks.

Another option that is available is that of telecommunications. Technology can fill in the seams of time and afford more opportunities for reaching a larger segment of the student market. This technology is a viable alternative as well as a reliable supplement to instruction and bridges distance and time.

Language education has been and continues to be an ongoing issue in business school study abroad programs. Effective communication is viewed by some as more than training in language skills for business. "Our students need to be sensitized to cultural differences, their own culture ... so that they can understand the norms and expectations in the linguistic and cultural context, be prepared for misunderstandings...their underlying reasons" (Cothran \& Gramberg, 2000). "While language proficiency leads cultural sensitivity, it does not, by itself, prepare students for effective decision-making in the international business environment" (Lashbrooke, Hult, Causgil, Yaprak, Knight, 2002). Other issues for consideration "when integrating foreign language into business curricula... is interplay between language content, business content, and overseas study"(Lashbrooke, Hult, Causgil,Yaprak, Knight, 2002). Questions still remain as to what is Business German. "If we let business be our guide then business language may be defined as language occurring in real life situations, and these situations are mapped out ...by the structure of business"(Cothran \& Gramberg, 2002).

Telecollaboration is defined as "the application of global electronic networks to foreign language education" so that "internationally dispersed learners [can] use technical communication tools such as email, synchronous chat, threaded discussion, or videoconferencing in order to support social interaction, discussion, debate, and intercultural exchange" (Kinginger, 2002). Technology "provides the opportunity to create course content and delivery of a highly robust, enriched and, yes, entertaining format that appeals to modern student learning desires (Sturges, 2006). Ethnographic research on the success of this technology (via video conferencing) mediated culture forum netted positive results, as students claimed 'the videoconference was the most memorable experience of their academic careers' (Sanders, 1997).

\section{Funding}

Affordability is a key ingredient for a successful program. The program will not succeed unless the cost is within a student's budget, (Praetzel, Curcio, \& DiLorenzo, 1996). When considering fundraising a marketing 
strategy should be considered to maximize all revenue streams. Donors need to know how their funds will be utilized.

Sources of funding that are available include scholarships, grants, financial aid, internships, endowments, fund raising activities, individuals(alumni) with study abroad experience or who have lived abroad as well as formal groups of external donors that include advisory boards and or small family foundations.

\section{CONCLUSIONS AND RECOMMENDATIONS}

There are numerous opportunities to create a successful study abroad program that would be created on a utilizing the departmental study abroad program that would serve as a foundation for further development. The faculty will serve a critical advisement and resource role in this development towards internationalization of the curriculum. Another benefit that will evolve from faculty involvement is the exchange and dialog with its foreign faculty counterparts which could evolve into research and faculty development opportunities. Finally, the students will gain the educational benefits by allowing a coordinated linkage between the curricula of the host and domestic institutions and gain a broader professional perspective. Ultimately the global business community will reap the harvest of effort in receiving a student who is understanding of other nations, languages and cultures in order to develop the appropriate level of confidence to function effectively in the rapidly emerging global environment.

\section{REFERENCES}

1. American Association of State Colleges and Universities. (1998). Global Responsibility: Final Report of the AASCU Task Force on Global Responsibility. Washington, D C: American Association of State Colleges and Universities

2. Bartell, Marvin (2003). Internationalization of Universities: A University Culture-Based Framework. Higher Education, Vol. 45, No. 1, 43 - 70.

3. Belz, Julie A. \& Mueller-Hartman, Andreus (2003). Teachers as Intercultural Learners: Negotiating German-American Telecollaboration along the Institutional Fault Line. The Modern Language Journal, Vol. 87, I, 71 - 89.

4. Bolten, Jurgen. Wirtschaftsdeutsch - quo vadis? Empirische Grundiagen fur die Erstellung von Lehrmaterialien, Handbook for German in Business and Technology. Ed. Bettina F. Cothran. Cherry Hill: American Association of Teachers of German, 1994. 9 - 26.

5. Cothram, Bettina F. \& Gramberg, Anne-Katrin (2000). Business German: The Next Step, the Birth of a New Discipline. Die Unterrichtspraxis / Teaching German, Vol. 33, No. 2, 148 - 171.

6. Gray, Kimberly, 2002. Assessing study abroad's effect on an international mission - Missouri Southern. Journal of Education for Business, 44 - 45.

7. Kininger, C. (2002), Defining the Zone of Proximal Development in US foreign language education. Applied Linguistics, Vol. 23, 240 - 261.

8. Lashbrooke, Jr. Elvin C., Hult, G. Thomas M., Cavusgil, S.Tamer, Yaprak, Attila, Knight, Gary A., (2000). Study Abroad Programs in Business Schools, Issues and Recommendations by Leading Educators, Report of the Michigan State University Center for International Business Education and Research, 2001 Roundtable on Study Abroad Programs in Business Schools

9. Janssens, Maddy (1995). Intercultural Interaction: A Burden on International Managers? Journal of Organizational Behavior, Vol. 16, No. 2, 155 - 167.

10. Praetzel, Gary D., Curcio, James, \& DiLorenzo, Joseph. (1996). Making Study Abroad a Realty for All Students. International Advances in Economic Research. Journal of Teaching in International Business, Vol. 2, No. 2, $174-181$.

11. Sporn, Barbara (1999). Current issues and future priorities for European higher education systems, in Altbach, P.G. and Peterson, P.M. (ed.) Higher Education in the $21^{\text {st }}$ Century:Global Challenge and National Response. New York: Institute of International Education, Report No. 29, 67 - 77.

12. Sturges, David L., Ozuna, Teo , (2006), Using Technology to Increase Critical-Thinking in Undergraduate Business Study, Journal of College Teaching and Learning, The Clute Institute for Academic Research, Vol. 3, No. 3, $43-49$. 
NOTES 